Invertebrate Biology 127(1): 80-86.

(C) 2008, The Authors

Journal compilation (C) 2008, The American Microscopical Society, Inc.

DOI: $10.1111 / \mathrm{j} .1744-7410.2007 .00117 . x$

\title{
Role of diurnal rhythm of oxygen consumption in emergence from soil at night after heavy rain by earthworms
}

\author{
Shu-Chun Chuang ${ }^{1}$ and Jiun Hong Chen ${ }^{1,2, a}$ \\ ${ }^{1}$ Institute of Zoology, National Taiwan University, Taipei, Taiwan \\ ${ }^{2}$ Department of Life Science, National Taiwan University, Taipei, Taiwan
}

\begin{abstract}
Two species of earthworms were used to unravel why some earthworm species crawl out of the soil at night after heavy rain. Specimens of Amynthas gracilis, which show this behavior, were found to have poor tolerance to water immersion and a diurnal rhythm of oxygen consumption, using more oxygen at night than during the day. The other species, Pontoscolex corethrurus, survived longer under water and was never observed to crawl out of the soil after heavy rain; its oxygen consumption was not only lower than that of $A$. gracilis but also lacked a diurnal rhythm. Accordingly, we suggest that earthworms have at least two types of physical strategies to deal with water immersion and attendant oxygen depletion of the soil. The first is represented by A. gracilis; they crawl out of the waterlogged soil, especially at night when their oxygen consumption increases. The other strategy, shown by $P$. corethrurus, allows the earthworms to survive at a lower concentration of oxygen due to lower consumption; these worms can therefore remain longer in oxygen-poor conditions, and never crawl out of the soil after heavy rain.
\end{abstract}

Additional key words: rain, earthworm crawling, oxygen consumption

Darwin (1881) observed that, after heavy rain, many dead earthworms could be found lying on the soil surface. He considered that these earthworms were sick and that the heavy rain had hastened their death. Lankester (1921) suggested that earthworms were found dead on the soil surface because of lack of oxygen in the groundwater, implying that earthworms might drown when submerged in water. However, some earthworm species can remain alive in water for several days; as oxygen diffuses through their moist skin, they should survive under water for at least some time, as suggested by Nagano (1934). Nagano further suggested that lack of oxygen could be a primary cause of earthworm death while under water. However, this does not explain why some earthworm species crawl out of the soil after heavy rain, and do so only at night.

In Taiwan, some species of earthworm, including Amynthas gracilis KINBERG 1867, Amynthas aspergillum, Amynthas robustus, and Metaphire schmardae, can be observed dispersed on the soil surface after heavy rain (Tsai 1964). Because some earthworm species have been demonstrated experimentally to have a

\footnotetext{
${ }^{a}$ Author for correspondence. E-mail: chenjh@ntu.edu.tw
}

diurnal rhythm of oxygen consumption, with a high rate of consumption at night and a low rate during the day (Ralph 1957; Chuang et al. 2004), we suspected that the reason for earthworms leaving the soil may be their rate of oxygen consumption and tolerance of water submersion. On the other hand, because earthworms live in the soil, their physical condition and crawling behavior may be affected by chemicals entering solution, such as acid (soil pH) or heavy metals (Chen \& Liu 2006), in flooded burrows (Gupta et al. 1999; Spurgeon et al. 2004). To examine this phenomenon, two common earthworm species in Taiwan were chosen: A. gracilis was selected as the positive model, as its members are known to leave the soil during the night after heavy rain, while Pontoscolex corethrurus MüLLER 1856 was chosen as the control model species, as its members are never observed to leave the soil after rain.

\section{Methods}

\section{Earthworms}

Specimens of Amynthas gracilis (Megascolecidae) were collected from several fields in Taiwan. Pontoscolex corethrurus (Glossoscolecidae), formerly an exotic species but now widespread throughout Taiwan 
(Tsai et al. 2000), was collected in a park at National Taiwan University. The earthworms were raised in a photoperiod-controlled incubator under a $12: 12 \mathrm{~h}$ light:dark regime. The temperature was maintained at $25^{\circ} \mathrm{C}$ and the humidity of the soil at $\sim 70-80 \%$. Husks of rice and green bean sprouts were routinely mixed into the soil as the nutrient source. In order to exclude any effects of body weight, only mature earthworms weighing $0.6-0.8 \mathrm{~g}$ were used in this study.

\section{Crawling behavior tests}

The soil components used in this study were modified from a 1984 technical report of the Organization for Economic Co-operation and Development (OECD). Four hundred grams of soil $(70 \%$ loam and $30 \%$ sandy soil), with a humidity of $70 \%$ and a $\mathrm{pH}$ of 7.0 (soil moisture and $\mathrm{pH}$ meter; Soil Tester, Takemura Electric Works, Taipei, Taiwan), were packed into a circular container (radius $=10.5 \mathrm{~cm}$, height $=5 \mathrm{~cm}$ ). In order to mimic the mineral components of soil dissolved in rainwater, artificial spring water (ASW) (Pierce et al. 1984) was used. When testing the effects of water alone $(\mathrm{pH}$ 7.0), the ASW either just covered or was $1 \mathrm{~cm}$ above the soil surface. In the acidic-condition tests, the earthworms were kept in soil moistened, but not covered, with ASW at different $\mathrm{pH}$ values and $70 \%$ humidity. In the heavy-metal test, earthworms were maintained in moist soil ( $\mathrm{pH} 7.0,70 \%$ humidity) containing cadmium $\left(0,3,9.48\right.$, or $30 \mu \mathrm{g} \mathrm{Cd} \mathrm{g}{ }^{-1}$ dry soil). Each experiment was repeated on 20 different earthworms. These tests were performed at $25^{\circ} \mathrm{C}$ on a $12 \mathrm{~h}$ light dark ${ }^{-1}$ cycle. The tests were started at noon, and the number of earthworms that crawled out of the soil was recorded every hour. If the earthworms did not crawl out of the soil, their survival was checked after $72 \mathrm{~h}$.

\section{Survival rate in water}

To mimic the environmental conditions of earthworms in waterlogged soil, each earthworm was kept in a bottle (height $=4.7 \mathrm{~cm}$, diameter $=2.0 \mathrm{~cm}$, total volume $=17 \mathrm{~mL}$ ) filled with ASW. One earthworm was kept in a $90-\mathrm{mm}$-diameter plastic dish with moist \#1 filter paper as a control. All treatments were performed in a $25^{\circ} \mathrm{C}$, photoperiod-controlled incubator. Some bottles containing earthworms were left open to the air, while others were sealed with polyvinylchloride (PVC) membrane and modeling clay to prevent air dissolving in the water during the experiment. Earthworms were classified as dead when they did not respond to a gentle prodding of their pros- tomia with a sharp needle (OECD 1984), either directly (open bottles) or through the PVC membrane and clay (sealed bottles). If the earthworms were alive when tested, bottles were re-sealed and the experiment was continued. The residual oxygen concentration of the water was measured when an earthworm was classified as dead. Because the survival time in a Petri dish with wet filter paper of members of $P$. corethrurus was longer than those of $A$. gracilis, we ended the testing time at 96 and $72 \mathrm{~h}$, respectively. However, in sealed bottles, we ended the test at $76 \mathrm{~h}$ for $P$. corethrurus, because the water was becoming muddy. Each treatment was repeated on 20 worms.

\section{Oxygen consumption}

Oxygen consumption was measured using a biological oxygen meter (YSI5300, YSI 5301, Yellow Springs Instruments, Yellow Springs, OH, USA) as described in Chuang et al. (2004). Briefly, an earthworm was placed in a water chamber filled with $12 \mathrm{~mL}$ of air-saturated water, and the oxygen concentration was measured every $15 \mathrm{~min}$ for $2 \mathrm{~h}$ (Clark-type oxygen electrode) at $25^{\circ} \mathrm{C}$. The oxygen concentration in a chamber with no earthworm was used as the negative control and was found to decrease $\sim 5-7 \%$ at the beginning, but soon stabilized for the $2 \mathrm{~h}$.

Air-saturated water at normal atmospheric pressure and various temperatures contains $X \mathrm{mg} \mathrm{O}_{2} / \mathrm{mL}$, which was recorded using a digital oxygen meter (Lutron, Do 5510, Taipei, Taiwan), so that $Y \mathrm{mLs}$ contains $X \times Y \mathrm{mg}$ of $\mathrm{O}_{2}$. When an earthworm weighing $G \mathrm{~g}$ causes the oxygen concentration of the water to decline by $Z \%$ (the oxygen percentage in the chamber with a earthworm minus that with no earthworm) in $t \mathrm{~min}$, the rate of oxygen consumption is $(X \times Y \times Z \%) \times t / 60 \mathrm{mgh}^{-1}$, and the oxygen consumption rate of a unit weight (g) of earthworm $\left(\mathrm{mgh} \mathrm{g}^{-1}\right)$ is $[(X \times Y \times Z \%) \times t / 60] / G$.

Rates of oxygen consumption by individuals of A. gracilis and $P$. corethrurus were determined over three periods, namely morning (04:00-06:00 hours), mid-day (11:00-13:00 hours), and night (19:00-21:00 hours); these periods were chosen on the basis of pilot studies. Each treatment was tested using six worms.

\section{Statistical analysis}

The effects of the different conditions on crawling out of the soil were tested using the $\chi^{2}$ distribution. Two-way ANOVA and Duncan's test were used to analyze differences in earthworm survival rates. The accumulated oxygen consumption of the two species 
of earthworms during the different time periods was analyzed by a nested design and least-significant difference test. A probability of $\mathrm{p}<0.05$ was accepted as significant.

\section{Results}

\section{Conditions affecting emergence}

At a normal soil humidity of $70-80 \%$, individuals of Amynthas gracilis always remained in the soil, but crawled out in $\leq 17 \mathrm{~h}$ when water reached the soil surface, or in $\leq 10 \mathrm{~h}$ when the surface was submerged to $1-\mathrm{cm}$ depth (Table 1). In contrast, under acidic conditions or in the presence of cadmium, they did not crawl out of the soil $\left(\chi^{2}\right.$ distribution, $\left.\mathrm{p}<0.001\right)$. None of the earthworms died in the water saturation or acidic-condition tests, and only $20 \%$ died when exposed to 0,3 , or $9.48 \mu \mathrm{g} \mathrm{g}^{-1}$ of cadmium. Apart from one individual, exposed to $30 \mu \mathrm{g} \mathrm{g}^{-1}$ of cadmium, individuals of Pontoscolex corethrurus did not crawl out of the soil under any of the conditions tested $\left(\chi^{2}\right.$ distribution, $\mathrm{p}=0.89>0.05$ compared with $70 \%$ humidity, $\mathrm{pH} 7.0$ ).

\section{Survival in water}

The mean survival time of specimens of $A$. gracilis in water was $5.4 \pm 1.34 \mathrm{~h}$ in a sealed bottle and
$13.4 \pm 6.95 \mathrm{~h}$ in an open bottle (Fig. 1). A control earthworm remained alive for $>72 \mathrm{~h}$ (end of testing) in a humidity box. However, individuals of $P$. corethrurus survived longer than those of A. gracilis under the same conditions, surviving in water for $45.4 \pm 3.58 \mathrm{~h}$ in a sealed bottle, to the end of the test (96h) in an open bottle, and for $\geq 96 \mathrm{~h}$ (end of test) in a humidity box. The differences between the species were significant $(p<0.001)$. The survival time for both species was longer in open bottles than in sealed bottles, the difference being highly significant $(p<0.001)$. Because there was no significant difference ( $p=0.592>0.05)$ among the weights of individual worms or between the two species, the influence of body weight on oxygen consumption was not a factor in this study.

The ASW was saturated with air by vigorous stirring immediately before an earthworm was placed in the bottle. The oxygen concentration of the ASW in the bottles before an earthworm was added was $5.86 \pm 0.4 \mu \mathrm{g} \mathrm{mL}^{-1}$ at $25^{\circ} \mathrm{C}$. When specimens of $A$. gracilis were classified as dead, the mean residual oxygen concentration in the ASW in sealed or open bottles was 1.87 or $1.5 \mu \mathrm{g} \mathrm{mL}^{-1}$, respectively (Fig. 2). However, individuals of $P$. corethrurus could survive until the mean oxygen concentration in a sealed or open bottle declined to 0.73 or $0.64 \mu \mathrm{g} \mathrm{mL}^{-1}$, respectively. The minimal oxygen concentration for survival of the two species differed significantly $(\mathrm{p}<0.05)$.

Table 1. Results of crawling experiments.

\begin{tabular}{|c|c|c|c|c|c|c|}
\hline \multirow[t]{2}{*}{ Treatment } & \multicolumn{2}{|c|}{$\begin{array}{l}\text { Number crawling } \\
\text { out of soil }(n=20)\end{array}$} & \multicolumn{2}{|c|}{$\begin{array}{l}\text { Average time to crawl } \\
\text { out of soil }(\mathrm{h})\end{array}$} & \multicolumn{2}{|c|}{$\begin{array}{l}\text { Mortality in } \\
3 \mathrm{~d}(\%)\end{array}$} \\
\hline & $\begin{array}{l}\text { Amynthas } \\
\text { gracilis }\end{array}$ & $\begin{array}{l}\text { Pontoscolex } \\
\text { corethrurus }\end{array}$ & $\begin{array}{c}\text { A. } \\
\text { gracilis }\end{array}$ & $\begin{array}{c}P . \\
\text { corethrurus }\end{array}$ & $\begin{array}{c}\text { A. } \\
\text { gracilis }\end{array}$ & $\begin{array}{c}P . \\
\text { corethrurus }\end{array}$ \\
\hline \multicolumn{7}{|l|}{ Water (pH 7) } \\
\hline Humidity $70 \%$ & 0 & 0 & - & - & 0 & 0 \\
\hline Water to soil surface & 20 & 0 & $17 \pm 0.8$ & - & 0 & 0 \\
\hline Water $1 \mathrm{~cm}$ higher than soil surface & 20 & 0 & $10 \pm 1.2$ & - & 0 & 0 \\
\hline \multicolumn{7}{|l|}{ pH (humidity $70 \%$ ) } \\
\hline 4.0 & 0 & 0 & - & - & 0 & 0 \\
\hline 5.0 & 0 & 0 & - & - & 0 & 0 \\
\hline 6.0 & 0 & 0 & - & - & 0 & 0 \\
\hline 7.0 & 0 & 0 & - & - & 0 & 0 \\
\hline 8.0 & 0 & 0 & - & - & 0 & 0 \\
\hline \multicolumn{7}{|l|}{ Cadmium $\left(\mu \mathrm{g} \mathrm{g}^{-1}\right)$ (humidity $70 \%, \mathrm{pH} 7$ ) } \\
\hline 0 & 0 & 0 & - & - & 0 & 0 \\
\hline 3 & 0 & 0 & - & - & 20 & 0 \\
\hline 9.48 & 0 & 0 & - & - & 20 & 0 \\
\hline 30 & 0 & 1 & - & 26 & 0 & 20 \\
\hline
\end{tabular}




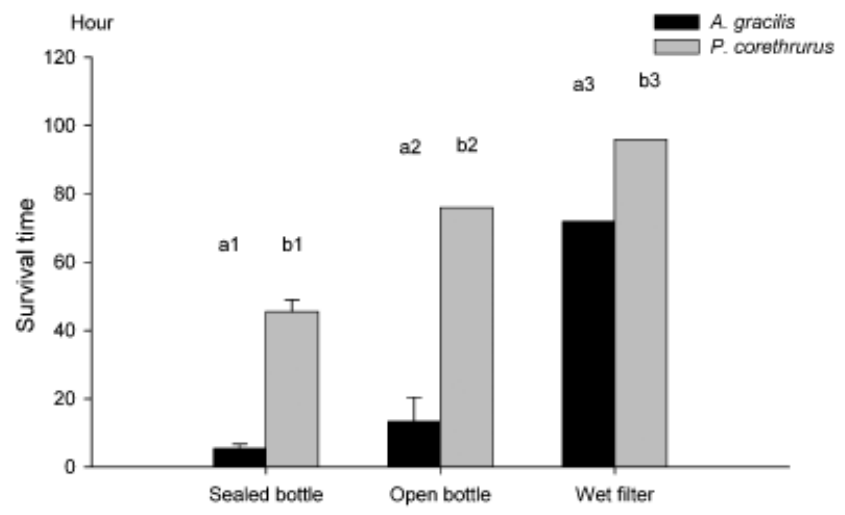

Fig. 1. Survival times of submerged earthworms (mean $\pm \mathrm{SD}, n=20$ ). Different letters and numbers indicate significant difference among treatments.

\section{Oxygen consumption versus time of day}

For $A$. gracilis, the average oxygen consumption for the period 11:00-13:00 hours was lower than that for the periods 19:00-21:00 and 04:00-06:00 hours (Fig. 3), and therefore showed a diurnal rhythm, being higher at night than in daytime. The cumulative oxygen consumption showed a significant difference between 11:00-13:00 hours and the other 2-h periods, while no difference was seen in oxygen consumption between the 19:00-21:00 and 04:00-06:00 periods (Fig. 3A, Table 2). In P. corethrurus, consumption did not differ significantly among time periods (Fig. 3B, Table 2). At 19:00-21:00 and 04:00-06:00 hours, the oxygen consumption in $A$. gracilis was significantly higher than in P. corethrurus (Fig. 3C).

\section{Discussion}

It is a common phenomenon to see earthworms crawling out of the soil during the night or morning

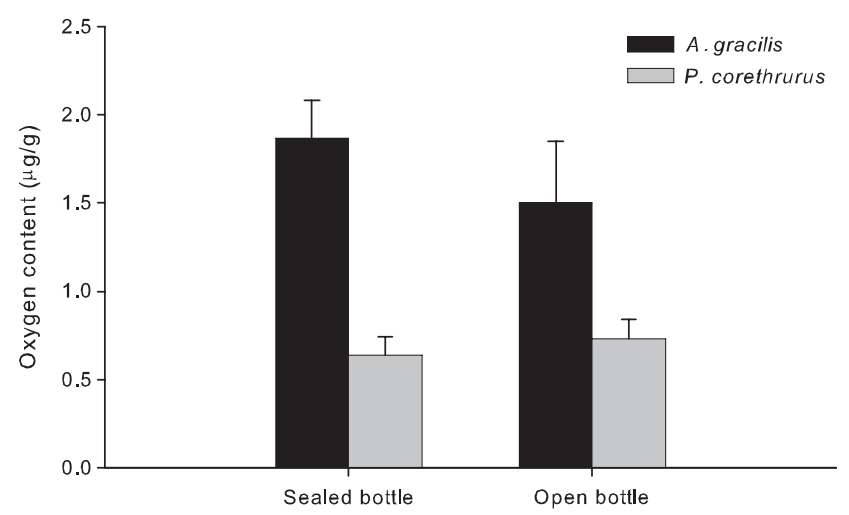

Fig. 2. Oxygen remaining (mean $\pm \mathrm{SD}, n=20$ ) in artificial spring water-containing bottles at $25^{\circ} \mathrm{C}$, measured immediately after the worm was found to be dead. Different letters indicate significant difference.
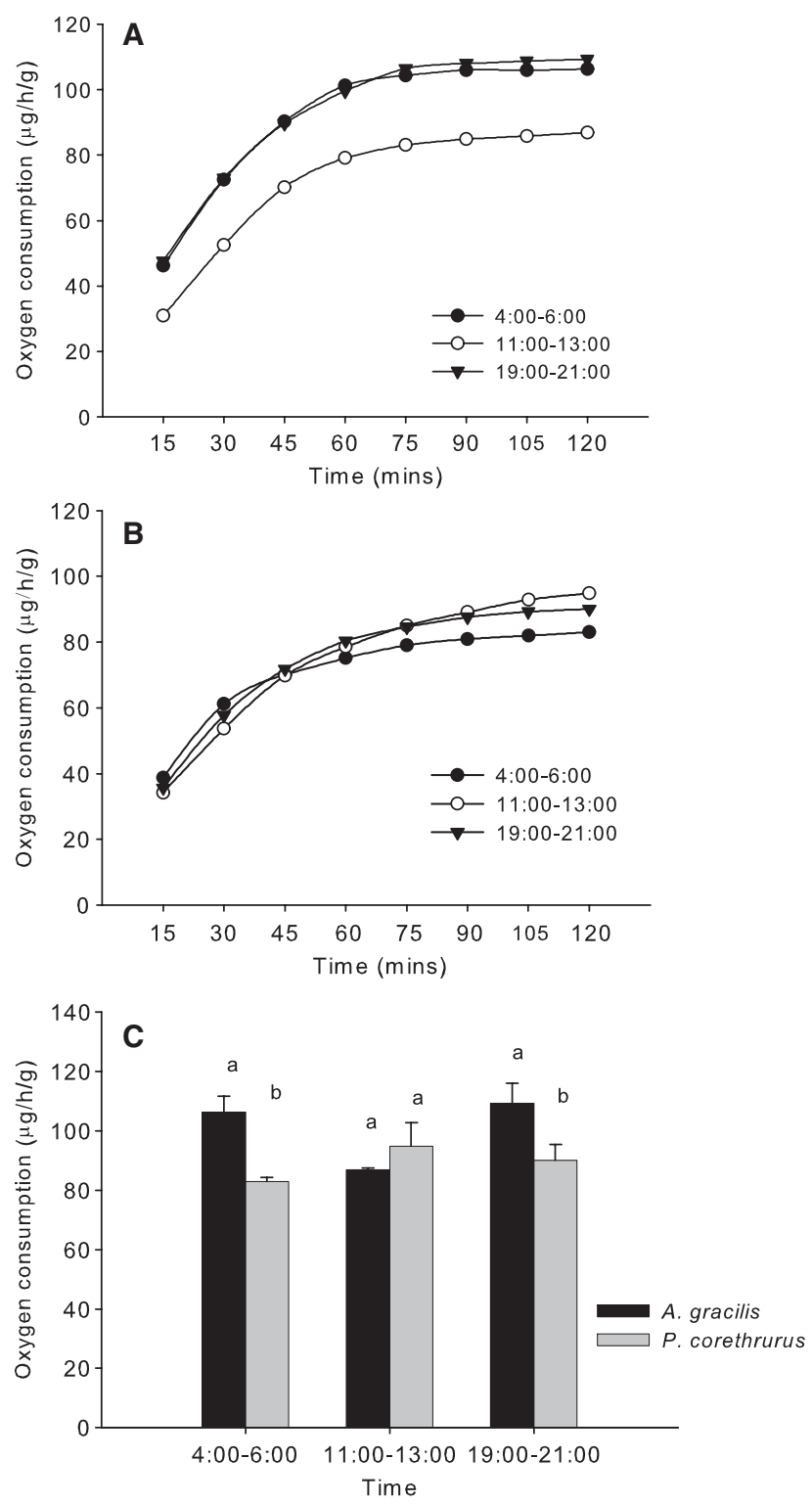

Fig 3. A. Cumulative oxygen consumption in Amynthas gracilis. Note the higher respiratory rate at night than in the daytime. B. Cumulative oxygen consumption in Pontoscolex corethrurus. Note the steady increase. C. Total oxygen consumption (mean $\pm \mathrm{SD}, n=6$ ) in 2-h periods at $25^{\circ} \mathrm{C}$ for $A$. gracilis and $P$. corethrurus. Different letters within time periods indicate significant differences between species.

after heavy rain. In the past, researchers thought that earthworms could drown in water (Lankester 1921). However, our results and other reports (Nagano 1934; Edwards \& Bohlen 1996) show that earthworms can respire in water and live for at least several hours or even days. Thus, there must be another factor driving earthworms out of the soil after heavy rain. 
Table 2. Comparison of the accumulated oxygen consumption at different time periods, measured every $15 \mathrm{~min}$ for $2 \mathrm{~h}$, using a nested design and a least-significant difference test. Numbers represent $\mathrm{p}$ values; the asterisks indicate significant differences.

\begin{tabular}{|c|c|c|c|c|c|c|}
\hline & \multicolumn{3}{|c|}{ Pontoscolex corethrurus } & \multicolumn{3}{|c|}{ Amynthas gracilis } \\
\hline & 04:00-06:00 & $11: 00-13: 00$ & $19: 00-21: 00$ & $04: 00-06: 00$ & 11:00-13:00 & $19: 00-21: 00$ \\
\hline \multicolumn{7}{|l|}{ P. corethrurus } \\
\hline 04:00-06:00 & • & 0.281 & 0.299 & $0.0001^{* *}$ & 0.8927 & $0.0001^{* *}$ \\
\hline $11: 00-13: 00$ & & $\bullet$ & 0.967 & $0.0001^{* *}$ & 0.345 & $0.0001^{* *}$ \\
\hline 19:00-21:00 & & & $\bullet$ & $0.0001^{* *}$ & 0.3663 & $0.0001^{* *}$ \\
\hline \multicolumn{7}{|l|}{ A. gracilis } \\
\hline 04:00-06:00 & & & & $\bullet$ & $0.0001^{* *}$ & 0.7193 \\
\hline 11:00-13:00 & & & & & $\bullet$ & $0.0001^{* *}$ \\
\hline 19:00-21:00 & & & & & & $\bullet$ \\
\hline
\end{tabular}

${ }^{*} \mathrm{p}<0.05{ }^{* *} \mathrm{p}<0.01$.

When soil is waterlogged, chemicals, such as heavy metals, might be put into solution. The heavy metal cadmium and acidic rain can affect some physical responses of earthworms, such as cocoon production or hatching (Gupta et al. 1999; Spurgeon et al. 2004). However, no significant influence of these factors on crawling behavior in Amynthas gracilis or Pontoscolex corethrurus was observed in this study, except that a few individuals died in the cadmium-containing soil. These results show that neither acidic rain nor cadmium is responsible for driving earthworms to escape the waterlogged soil.

Waterlogging significantly decreases the oxygen concentration in the soil (Drew 1983); water, with a lower oxygen concentration and diffusion rate, displaces air in soil pores. Therefore, once waterlogged, the oxygen concentration in soil decreases rapidly (Barrett-Lennard et al. 1986).

Some oligochaetes, such as Alma emini (Michaelsen 1892), can subsist in waterlogged swamps. The interstitial spaces in the soil are generally anoxic and the soil is highly reducing. Members of $A$. emini have evolved a remarkable unique respiratory strategy; the posterior-dorsal part of the body is converted into a "lung," across which gases are exchanged at the soil surface or under water (Maina et al. 1998). Terrestrial earthworms do not possess this respiratory strategy; although earthworms can respire in water for a period, they do not survive well in oxygen-poor water (Nagano 1934).

In this study, we measured the oxygen consumption of earthworms from a limited reservoir. Commonly, in oxygen-consumption studies, animals are maintained in a small vessel and bathed in flowing, oxygen-laden water for a period of time; after the test animal is acclimatized, the oxygen-saturated water flow is stopped, and oxygen consumption is measured. In this study, however, we wanted to mimic an unusual waterlogged environment. The limited oxygen reservoir of our test instrument, designed for measurement of oxygen consumption rate, appropriately fits the experimental design of this study where earthworms were exposed to waterlogged soil and consumed oxygen under a diffusion-limited condition. Accordingly, the earthworms were not kept in a resting state. In $A$. gracilis, because of the limited reservoir, the oxygen consumption rate decreased during the experiment; total consumption reached a plateau. On the other hand, while the consumption rate in $P$. corethrurus slowed, the total consumption continued to increase during the experiment. Correspondingly, at the end of the experiments, the water in which $A$. gracilis was tested retained a higher oxygen concentration than that of $P$. corethrurus. Therefore, we inferred that members of $P$. corethrurus can survive better than those of A. gracilis in water with a lower oxygen concentration, due to lower oxygen consumption or better oxygen uptake.

Some earthworms have been known to respire anaerobically for a period (Davis \& Slater 1928; Lee 1985; Edwards \& Bohlen 1996). In this study, the oxygen concentration in the water at the end of the experiment was found to be very low, and so it is possible that members of $P$. corethrurus can respire anaerobically under oxygen-poor conditions.

Members of A. gracilis crawled out of the soil 10$17 \mathrm{~h}$ from noon, at night, matching the diurnal rhythm of their higher oxygen consumption. Most terrestrial earthworms are more active at night (Chuang et al. 2004). Predation pressure (Christensen \& Mather 2001; Csermely 2003), especially from birds, might be a factor selecting against day emergence of earthworms during daytime. Ultraviolet light exposure may 
be another negative selection factor against daytime emergence (Merker \& Brägunig 1927), but the intensity of UV light is low on a rainy day and should not be strong enough to threaten the earthworms under waterlogged conditions due to heavy rain.

Other factors, such as sickness (Darwin 1881), mating, feeding, and migration (Edwards \& Bohlen 1996), might cause earthworms to emerge above ground. However, these factors were also excluded to explain our results for the following reasons. Firstly, the mating or feeding behavior of earthworms differs from their crawling behavior after rain. A study of mating behavior showed that an earthworm stretches its anterior section out onto the ground to make contact with another earthworm, leaving its posterior section in the soil (Nuutinen \& Butt 1997). This resembles its feeding behavior. According to our observations over the last 10 years, earthworms that crawl out of waterlogged soil never mate, even though they may be in close contact with one another. Secondly, the vast majority of earthworms that left the soil appeared to be healthy, because they could be maintained in our laboratory for several months (data not shown), thus excluding the possibility of illness.

In summary, our results support our hypothesis that the night-time emergence behavior of earthworms is mediated by their diurnal rhythm of oxygen consumption. Earthworms of some species, such as A. gracilis, have lower oxygen consumption during the daytime and can remain in waterlogged soil; at night, however, especially when waterlogging due to heavy rain reduces oxygen availability in the soil, greater activity and higher oxygen consumption drive the earthworms to crawl out of the soil in order to obtain more oxygen. In contrast, earthworms such as $P$. corethrurus, which have lower oxygen consumption with no diurnal rhythm, can tolerate reduced oxygen levels due to waterlogging and never emerge after heavy rain.

\section{References}

Barrett-Lennard EG, Leighton PD, McPharlin IR, Setter $\mathrm{T}, \&$ Greenway H 1986. Methods to experimentally control waterlogging and measure soil oxygen in field trials. Aus. J. Soil Res. 24: 477-483.

Chen CM \& Liu MC 2006. Ecological risk assessment on a cadmium contaminated soil landfill - a preliminary evaluation based on toxicity tests on local species and site-specific information. Sci. Total Environ. 359: 120-129.

Christensen OM \& Mather JG 2001. Long-term study of growth in the New Zealand flatworm Arthurdendyus triangulatus under laboratory conditions. Pedobiologia 45: 535-549.
Chuang SC, Lee H, \& Chen JH 2004. Diurnal rhythm and effect of temperature on oxygen consumption in earthworms, Amynthas gracilis and Pontoscolex corethrurus. J. Exp. Zool. 301A: 731-744.

Csermely D 2003. The predatory behaviour of common kestrels facing various types of prey. J. Ethol. 21: 107110.

Darwin C 1881. The Formation of Vegetable Mould Through the Action of Worms, with Observation of their Habits. John Murray, London.

Davis JB \& Slater WK 1928. The anaerobic metabolism of the earthworm Lumbricus terrestris. Biochem. J. 22: 338-343.

Drew MC 1983. Plant injury and adaptation to oxygen deficiency in the root environment: a review. Plant Soil 85: 361-373.

Edwards CA \& Bohlen PJ 1996. Biology and Ecology of Earthworms. Chapman \& Hall, New York. $426 \mathrm{pp}$.

Gupta SK, Murthy RC, \& Saxena DK 1999. Effect of cadmium on the hatching of Metaphire posthuma cocoons. Biomed. Environ. Sci. 12: 50-53.

Lankester ER 1921. Earthworms drowned in puddles. Nature 107: 329-330.

Lee KE 1985. Earthworms. The Ecology and Relationships with Soils and Land Use. Academic Press, North Ryde, Australia. $411 \mathrm{pp}$.

Maina JN, Maloiy GMO, \& Wood CM 1998. Respiratoy stratagems, mechanisms, and morphology of the 'lung' of a tropical swamp worm, Alma emini Mich. (Oligochaeta: Glossoscolecidae): a transmission and scanning electron microscope study, with field and laboratory observations. J. Zool. London 245: 483-495.

Merker E \& Bräunig G 1927. Die Empfindlichkeit feucchthäutiger Tiere im Lichte. 3. Die Empfindlichkeit feucchthäutiger Tiere im Licht der Quarzquecksiblerlampe. Zool. Jb. Abt. Allgem. Zool. Physiol, Tiere 43: 275-338.

Nagano T 1934. The duration of life of earthworms in water and in pure gases. Sci. Rep. Tohoku Imp. Univ. (B) 9: 97-109.

Nuutinen V \& Butt KR 1997. The mating behaviour of the earthworm Lumbricus terrestris (Oligochaeta: Lumbricidae). J. Zool. 242: 783-798.

OECD 1984. Earthworm acute toxicity tests. OECD guideline for testing of chemicals. 207: 1-9.

Pierce BA, Hoskins JB, \& Epstein E 1984. Acid tolerance in a Connecticut wood frog (Rana sylvatica). J. Herpetol. 18: $159-167$.

Ralph CL 1957. Persistent rhythms of activity and $\mathrm{O}_{2}$ consumption in the earthworm. Physiol. Zool. 30: 41-55.

Spurgeon DJ, Sturzenbaum SR, Svendsen C, Hankard PK, Morgan AJ, Weeks JM, \& Kille P 2004. Toxicological, cellular and gene expression responses in earthworms exposed to copper and cadmium. Comp. Biochem. Physiol. 138C: 11-21. 
Tsai CF 1964. On some earthworms belonging to the genus Pheretima Kinberg collected from Taipei area in North Taiwan. Quart. J. Taiwan Mus. 17: $1-35$.
Tsai CF, Shen HP, \& Tsai SC 2000. Occurrence of exotic earthworm Pontoscolex corethrurus (Möller) (Glosscolecidae: Oligochaeta) in Taiwan. End Species Res. 2: $68-73$. 